\title{
Static load behavior and energy absorption of safety guardrails for construction works
}

\section{Comportamiento bajo cargas estáticas y absorción de energía de barandillas de seguridad para obras}

\author{
Alfonso Cobo Escamilla (Main and Contact Author) \\ Technical University of Madrid, Department of Building Technology. \\ Escuela Técnica Superior de Edificación. Avda. Juan de Herrera, 6, 28040 Madrid (SPAIN) \\ alfonso.cobo@upm.es
}

María de las Nieves González García

Technical University of Madrid, Department of Architectural Constructions

mariadelasnieves.gonzalez@upm.es

Nuria Llauradó Pérez

Technical University of Madrid, Department of Building Technology

nuria.llaurado@upm.es

Manuscript Code: 500

Date of Acceptance/Reception: 01.08.2016/23.10.2014

\begin{abstract}
One of the requirements which must be met by the temporary edge protection systems (TEPS) is to stop a worker who walks, stumbles, falls and knocks against the system. The effect of the worker's crash with the protection system is a dynamic type stress applied as an impact. The capacity of the system to withstand the impact depends on its ductility and its ability to absorb energy. The area enclosed by the load-displacement graph of a TEPS when the load is statically applied is an indicator of its ductility and its ability to absorb energy. In Europe, the EN 13374 standard specifies the requirements to be fulfilled by the TEPS. For systems placed in floor slabs with a slope smaller than $10^{\circ}$ (class $\mathrm{A}$ systems), the standard indicates that the testing should be performed using static loads. In this work, TEPS manufactured from steel, wood, injected plastic, and composites have been tested with the static loads test system specified in the EN 13374 standard for assessing class A systems. Subsequently, the areas enclosed in the load-displacement diagram have been tested and have been compared with the estimated values of impact energy.
\end{abstract}

Keywords: safety guardrails, energy absorption, static load, accident, construction.

Resumen

Uno de los requisitos que deben satisfacer los sistemas provisionales de protección de borde (SPPB) es detener a un trabajador que camina, tropieza, cae y golpea contra el sistema. El efecto del choque del trabajador supone una acción de tipo dinámico aplicada en forma de impacto. La capacidad del sistema para resistir el impacto depende de su ductilidad y de su capacidad para absorber energía. El área encerrada por la gráfica carga desplazamiento de un TEPS cuando la carga se aplica de forma estática, es un indicador de su ductilidad y de su capacidad para absorber energía. En Europa, la norma EN 13374 especifica los requisitos que deben cumplir los SPPB. Para sistemas colocados en forjados con una inclinación no superior a 10으 (sistemas clase A), la norma indica que la evaluación se debe realizar mediante cargas estáticas. En este trabajo se han ensayado TEPS fabricados en acero, madera, plástico inyectado y composites con el sistema de cargas estáticas especificadas por la norma EN 13374 para la evaluación de sistemas como clase A. Posteriormente se han evaluado las áreas encerradas en el diagrama carga desplazamiento y se han comparado con los valores estimados de energía de impacto.

Palabras clave: barandillas de seguridad, absorción de energía, carga estática, accidente, construcción.

Introduction

\section{Description of the problem}

The construction industry has one of the highest accident rates worldwide (López-Arquillos \& Rubio-Romero, 2015). Accidents in construction works due to fall from heights are globally a high percentage of the total number of those which take place in the building sector (BLS, 2010; Ministerio de Trabajo y Asuntos Sociales, 2008; National Safety Council, 2002; OSHA, 1990; SESS, 1999). Protection systems that prevent the fall of workers should be preferably used against other types of systems that only limit the height to prevent or limit injuries (INRS, 2007; OSHA, 1990). Protection against fall from heights using a temporary edge protection system (TEPS) is effective because it eliminates the risk in origin altogether, preventing the fall. Unfortunately, to date, the vast majority of the TEPS used in building construction works have not been subjected to prior assessment and their structural behavior is not known. 


\section{State of the art}

The norms studied that regulate TEPS (AENOR, 2013; ASTM, 1987; Australian Standard, 1992; eLCOSH, 2008; OSHA, 1998) require them to meet geometric and mechanical type requirements. Geometric type requirements establish the TEPS dimensions, so that neither the worker surpasses the system and falls, nor objects pass from the slab to the vacuum. Mechanical requirements compel a certain resistance to the system and limit the movements against given loads. The EN 13374 (AENOR, 2013) standard specifies the performance requirements and testing methods for TEPS used during the construction or maintenance of buildings and other structures.

The standard classifies TEPS into three classes (A, B and C), in accordance with the inclination of the working surface and the fall height of the person to protect (Figure 1). The standard indicates the requirements, geometrical and mechanical, which TEPS must be met depending on the class they belong to. The most widely used Class $A$ systems can only be used when the inclination angle of the working surface is smaller than $10^{\circ}$. These systems are designed to stop a worker who stumbles, falls and knocks against the system. The effect of this crash is a dynamic force, however the EN 13374 standard specifies an evaluation system based on static loads, which is equivalent to the impact of a worker. Some works assess the energy of that impact as $160 \mathrm{~J}$ (Jacmin \& Mayer, 1984; Lan \& Daigle, 2005) or 180 J (AFNOR, 2010), obtained as the kinetic energy of a worker of 80 to $90 \mathrm{~kg}$ of weight that moves at a speed of $2 \mathrm{~m} / \mathrm{s}$.

\section{Methodology}

In this work we have tested TEPS manufactured from different materials in accordance with the requirements established by the EN 13374 standard for evaluating class A systems. Later, the energies in the static tests for the evaluation of class A systems performed were obtained by measuring the area enclosed in the load-displacement diagram during the test. Subsequently, the values obtained where then compared with the $180 \mathrm{~J}$ value. The analysis of the results allows us to determine the validity of the assessment procedure prescribed by the standard to predict the behavior of TEPS against impacts.

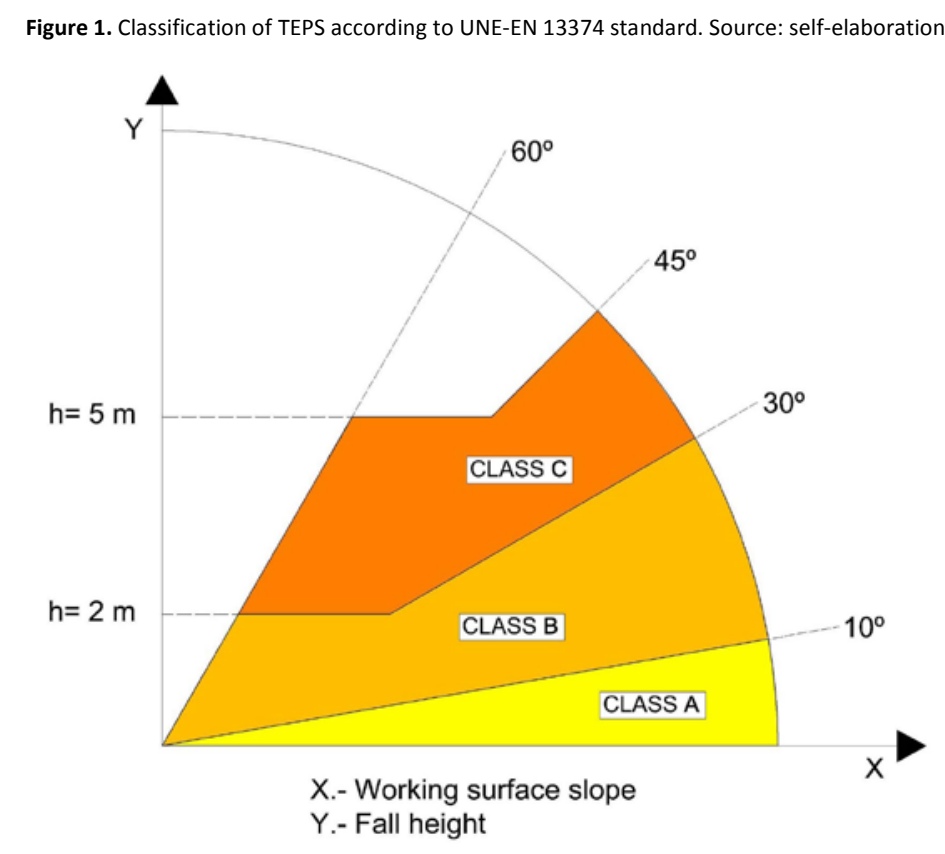

\section{Assessment of Class A TEPS}

In accordance with the EN 13374 standard, the calculation for static loads must be made by analyzing three situations: service limit state (SLS), ultimate limit state (ULS), and accidental load (AL).

Experimentally, testing SLS and ULS is carried out by applying specific horizontal loads according to the load cycle described below. An initial $0.10 \mathrm{kN}$ load is applied to the system. This load is maintained for one minute, and then the system is unloaded leaving it with a residual displacement which constitutes the reference displacement. Then, the corresponding test load is applied maintaining it for one minute, and after that, the system is unloaded. 
To meet standard of the SLS, the displacement of the system should not be greater than $55 \mathrm{~mm}$ when a load FT1 of $0.30 \mathrm{kN}$ is applied anywhere except on the toe board, where the load applied, FT2, is $0.20 \mathrm{kN}$. Testing the SLS is equivalent to assessing the displacement requirements. In order to comply with the ultimate limit state (ULS) stated, the system must be capable of withstanding the strength test without fracturing, Fmáx, which is obtained as Fmáx $=\gamma \mathrm{F}$ - $\mathrm{YM} \cdot \mathrm{QK}$, where $\mathrm{YF}$ y $\mathrm{YM}$ are partial safety coefficients for ULS (load increase factor and strength reduction factor respectively), and $\mathrm{QK}$ is the characteristic load according to the element considered. The strength reduction coefficient of the materials adopts a value of 1.1 for ductile materials, such as plastic or steel, and 1.3 for wood. The load increase factor is 1.5 for all cases. Once this force is achieved, the system is loaded up to a value $20 \%$ higher than the maximum test load (ultimate strength) and the system must not experience any notable failures globally or individually in each of the elements composing it.

The study of accidental loads indicated that the top guardrail, the middle one and the plinth must resist a gravitational specific load of FD $=1.25 \mathrm{kN}$. This load should be applied at the most unfavorable position of the TEPS, within an inclined angle of $\pm 10^{\circ}$ in relation to the vertical. However, complying with this test requirement does not allow concluding that the TEPS satisfies the requirements for which it is designed. The load taking place on a TEPS when a worker hits it, is a dynamic force which materializes in the form of impact. We do not know whether the evaluation of the static type load stated in the EN 13374 standard implies overcoming an impact produced by the fall of a worker, which is approximately equivalent to $180 \mathrm{~J}$ of energy. The area enclosed in the load-displacement diagram made during the ULS testing is a measure of the energy absorbed in the test; and the comparison of that value with $180 \mathrm{~J}$ indicates the validity of the static test design to predict impact behavior.

Testing performed

\section{Steel made TEPS}

Three TEPS have been analyzed spanning in between the posts 2,400 $\mathrm{mm}$ and with a height of 1,000 mm, measured from the reference level up to the top edge of the top guardrail. The main and mid rails as well as the posts were made using tubular S235 steel sections. For the post tabs, steel S275 was used. The telescopic toe board was manufactured with cold rolled steel sheet.

Table 1 lists the geometric characteristics of the three systems.

Table 1. Geometric characteristics of the systems with steel guardrails. Source: self-elaboration.

\begin{tabular}{|l|c|c|c|}
\hline & System 1(S1) & System 2 (S2) & System 3 (S3) \\
\hline GUARDRAILS & $025 \cdot 1.5 \mathrm{~mm}$ & $040 \cdot 1.5 \mathrm{~mm}$ & $040 \cdot 2 \mathrm{~mm}$ \\
\hline POSTS & $040 \cdot 1.5 \mathrm{~mm}$ & $035 \cdot 1.5 \mathrm{~mm}$ & $040 \cdot 2 \mathrm{~mm}$ \\
\hline TOE BOARD & \multicolumn{2}{|c|}{ telescopic, manufactured with cold rolled steel sheet } \\
\hline
\end{tabular}

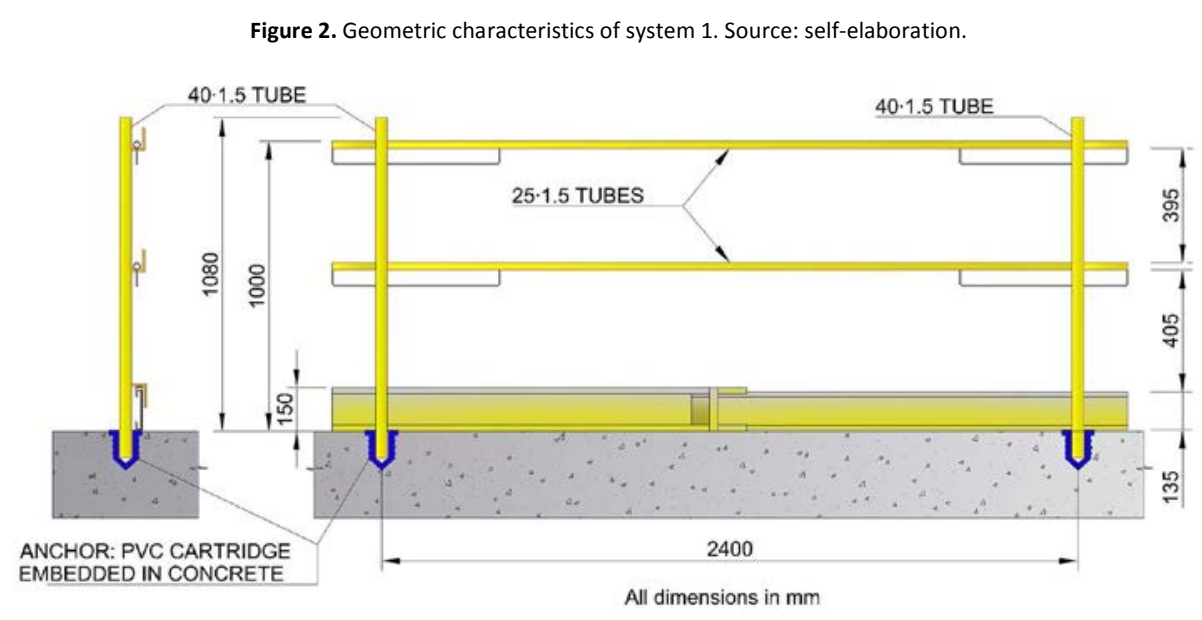

The three systems were anchored to a reinforced concrete beam that had PVC sleeves embedded ready to hold the posts of circular section $40 \mathrm{~mm}$ in diameter. Figure 2 shows, as an example, the layout and the geometrical characteristics of system 1 (González, Cobo, Castaño \& Prieto, 2015). 
Dimensions of the S1 system are the ones usually employed for edge protection of slabs in construction. The second system is used in special cases. The dimensions of the third system have been determined after making an analytical calculation based on the EN 13374 standard. (González, 2010; González, Cobo, Fuente, Bresó \& Lozano, 2010).

\section{Wood made TEPS}

For assessing the behavior of wood as guardrails and toeboards of TEPS, wooden pine planks Pinus Sylvestris L (PNSY), Iberian variety Svob, from the Central mountain range, Sierra de Guadarrama, have been used, supplied by the sawmill Aserradero El Espinar, located in Segovia. This wood corresponds to high-quality pine stock. The most common system of wooden TEPS has been considered, consisting of top and mid rails and a baseboard of wooden planks.

Figure 3 shows a drawing of one of the tested TEPS. It consists of the railings and toeboard made of wood, and beamembedded metal posts separated $2.40 \mathrm{~m}$. The posts are made of circular section steel S235. The wooden boards have a height of $150 \mathrm{~mm}$ and a thickness of $22 \mathrm{~mm}$ (S4, S5, and S6 systems), $27 \mathrm{~mm}$ (S7, S8 and S9), and $30 \mathrm{~mm}$ (S10, S11 and S12) forming the railings and the baseboard (Gonzalez, 2010). The visual classification of the wooden parts of S4, S7, and S10 systems was ME1, which corresponds to a C27 resistance class (AENOR, 2011; AENOR, 2010). S5, S8 and S11 systems have obtained a ME2 visual classification (resistance class C18). S6, S9 and S12 systems could not be assigned any resistant class due to their visual classification as rejected (table 2 ).

Figure 3. Draft of a class A TEPS with horizontal wooden elements. Source: self-elaboration.

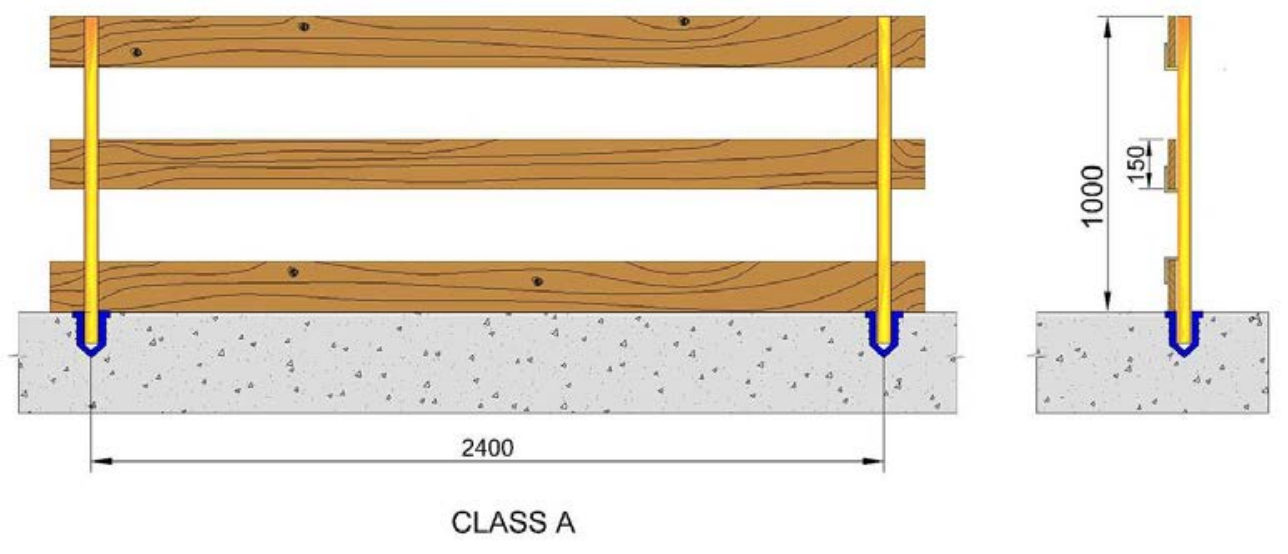

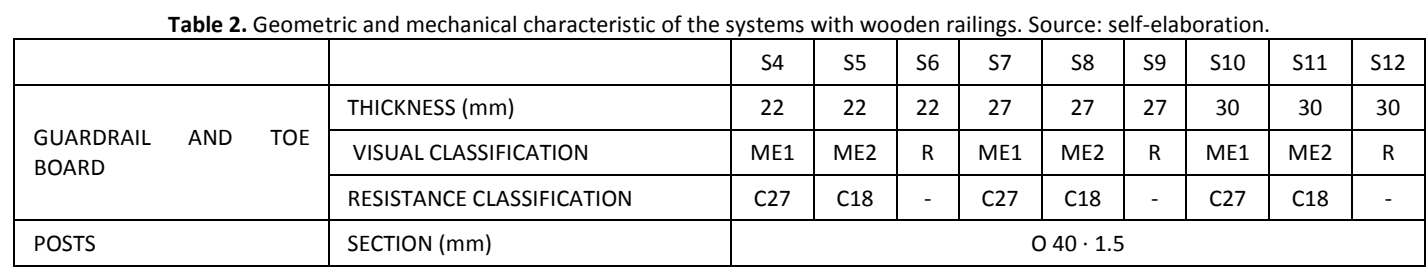

\section{TEPS made of high density polyethylene (HDPE)}

A TEPS formed by a fence made of injected HDPE with a density of $951 \mathrm{~kg} / \mathrm{m} 3$ and a stabilization treatment against ultraviolet (UV) radiation of $4 \%$ has been used. Another system made of a HDPE composite and glass fiber (GF) have also been studied. The influence of aging has been studied on TEPS made with HDPE and subjected to natural ageing. (González, Cobo, Lozano \& Bresó, 2013). 


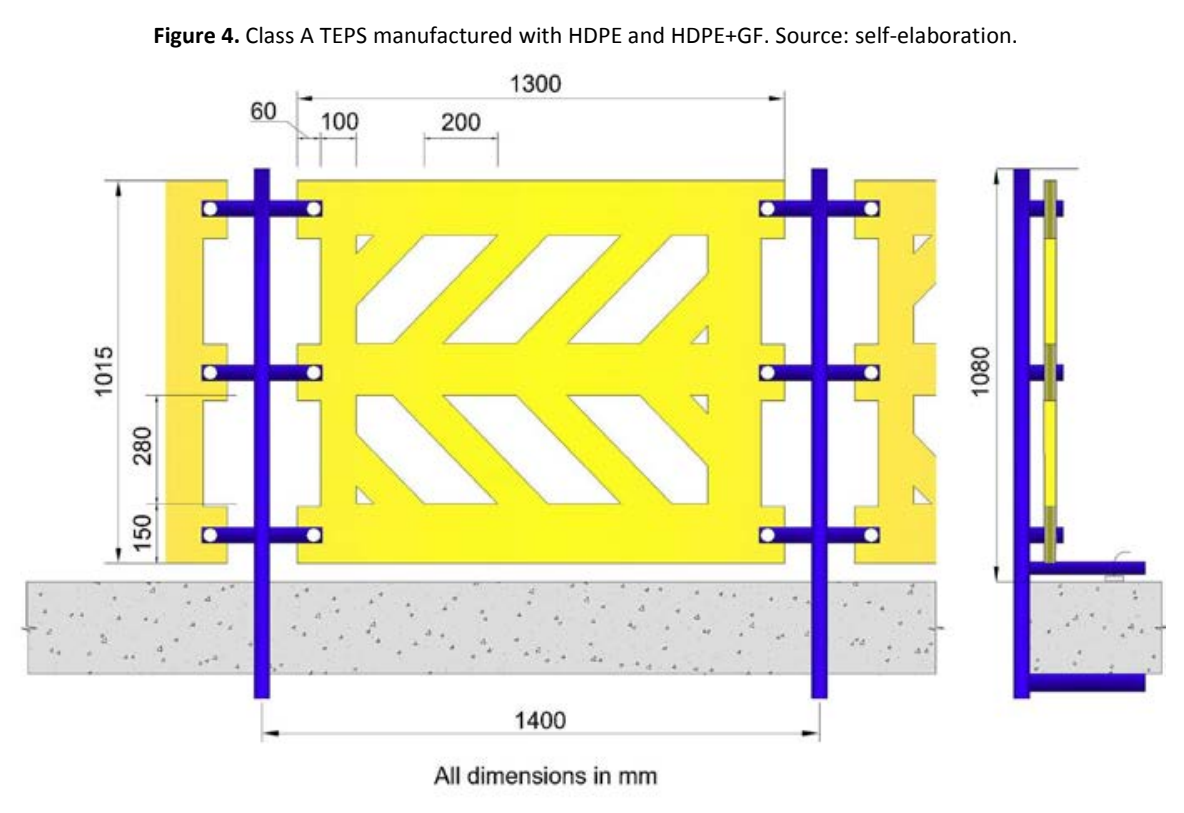

The continuous fence is formed by three horizontal elements, $150 \mathrm{~mm}$ in height, two vertical elements at the edges, and diagonal elements $200 \mathrm{~mm}$ wide with intermediate spaces located at the top and bottom rectangular spaces. The fence is tied by anchors inserted in the vertical posts. The posts are separated $1,400 \mathrm{~mm}$, and have been manufactured in steel S235 with a square tubular section of $35.1 .5 \mathrm{~mm}$, having a height of $1,080 \mathrm{~mm}$ over the slab level. The posts were anchored to a reinforced concrete beam by using a clamping jack. The internal side of the jack jaws, which is in contact with the structure support, has a toothed profile for improving the bonding of the jack with structure support (Figure 4). To evaluate the aging influence on the mechanical static loads behavior of the TEPS manufactured from HDPE, TEPS tests were carried out in a new state (S13) and exposed to natural aging for 1 year (S14), for 2.5 years (S15) in Cuenca. Tests of HDPE+GF systems were performed on elements without aging (S16).

\section{Experimental analysis methodology}

For the testing performed, a test frame was used with a load actuator. The movements were obtained with a displacement transducer. A control and data acquisition system registered the load data and displacement for each system test through specific software. Tests were performed with displacement control. The load was applied in a point located at the center of the top rail where the maximum displacement moment occurs and greater displacements were observed.

\section{Results obtained}

Table 3 shows the results of the 16 systems tested regarding SLS and ULS. The three columns corresponding to SLS indicate the results of the displacement test. In the first column the value of the maximum load applied can be seen, in the second one, the displacement obtained under the maximum load and in the third column, the value of the obtained energy in that test, measured as the area enclosed by the load-displacement curve. In the columns corresponding to the increased load factor and the ultimate strength values obtained in the ULS evaluation are shown, including identical information to the one indicated in the SLS columns. The last column shows the percentage value of the energy obtained from the ultimate strength test regarding $180 \mathrm{~J}$ value. The shaded cells with numerical values in bold correspond to values that do not comply with the requirements of the EN 13374 standard.

All systems correctly met the accidental load testing requirements. The behavior of all the systems studied when reaching the ultimate strength can be seen in figures 5-9, with the load applied at the central point of the top rail. A vertical line coincident with the $55 \mathrm{~mm}$ displacement is marked in all the graphs showing the maximum limit allowed in SLS tests by the EN 13374 standard when applying a 300N load. 
Table 3. Results of the static load tests performed. Source: self-elaboration.

\begin{tabular}{|c|c|c|c|c|c|c|c|c|c|c|}
\hline \multirow{3}{*}{ SSystem } & \multicolumn{3}{|c|}{ SLS } & \multicolumn{3}{|c|}{ INCREASE LOAD FACTOR } & \multicolumn{3}{|c|}{ ULTIMATE STRENGTH } & \\
\hline & Load & Displacement & Energy & Load & Displacement & Energy & Load & Displacement & Energy & \\
\hline & $(\mathrm{N})$ & $(\mathrm{mm})$ & $(\mathrm{J})$ & (N) & $(\mathrm{mm})$ & (J) & $(\mathrm{N})$ & $(\mathrm{mm})$ & $E_{3}(J)$ & $\left(E_{3} / 180 \mathrm{~J}\right) \%$ \\
\hline S1 & 300 & 66.7 & 10.2 & 500 & 138.2 & 34.9 & 600 & 185.9 & 55.8 & 31 \\
\hline S2 & 300 & 28.9 & 4.5 & 500 & 46.7 & 11.8 & 600 & 56.3 & 17.1 & 10 \\
\hline S3 & 300 & 21.7 & 3.3 & 500 & 37.2 & 9.4 & 600 & 44.7 & 13.8 & 8 \\
\hline S4 & 300 & 80.8 & 12.9 & 600 & 161.9 & 49.2 & 720 & 197.4 & 71.4 & 40 \\
\hline S5 & 300 & 60.6 & 10.6 & 600 & 121.7 & 37.3 & 720 & 146.8 & 53.5 & 30 \\
\hline S6 & 300 & 88.6 & 14.7 & 600 & 178.3 & 54.7 & 720 & 216.2 & 79.2 & 44 \\
\hline S7 & 300 & 49.6 & 7.8 & 600 & 99.5 & 30.6 & 720 & 119.8 & 43.7 & 24 \\
\hline S8 & 300 & 67.1 & 11.1 & 600 & 136.9 & 43.3 & 720 & 166.5 & 60.7 & 34 \\
\hline S9 & 300 & 81.4 & 12.6 & 600 & 180.2 & 56.1 & 720 & 218.6 & 78.6 & 44 \\
\hline S10 & 300 & 37.8 & 6.1 & 600 & 77.2 & 24.6 & 720 & 93.8 & 35.3 & 20 \\
\hline S11 & 300 & 38.5 & 6.2 & 600 & 78.1 & 25.8 & 720 & 94.7 & 35.9 & 20 \\
\hline S12 & 300 & 40.4 & 6.5 & 600 & 82.6 & 26.1 & 720 & 100.3 & 37.4 & 21 \\
\hline S13 & 300 & 98.2 & 15.1 & 500 & 148.3 & 37.1 & 600 & 173.5 & 53.1 & 30 \\
\hline S14 & 300 & 94.3 & 14.5 & 500 & 154.3 & 39.0 & 600 & 184.7 & 55.6 & 31 \\
\hline S15 & 300 & 99.2 & 15.2 & 500 & 155.9 & 39.2 & 600 & 186.4 & 56.3 & 31 \\
\hline S16 & 300 & 43.7 & 6.8 & 500 & 81.8 & 20.4 & 600 & 101.2 & 30.6 & 18 \\
\hline
\end{tabular}

Figure 5. Test results of steel protecting systems. Source: self-elaboration.

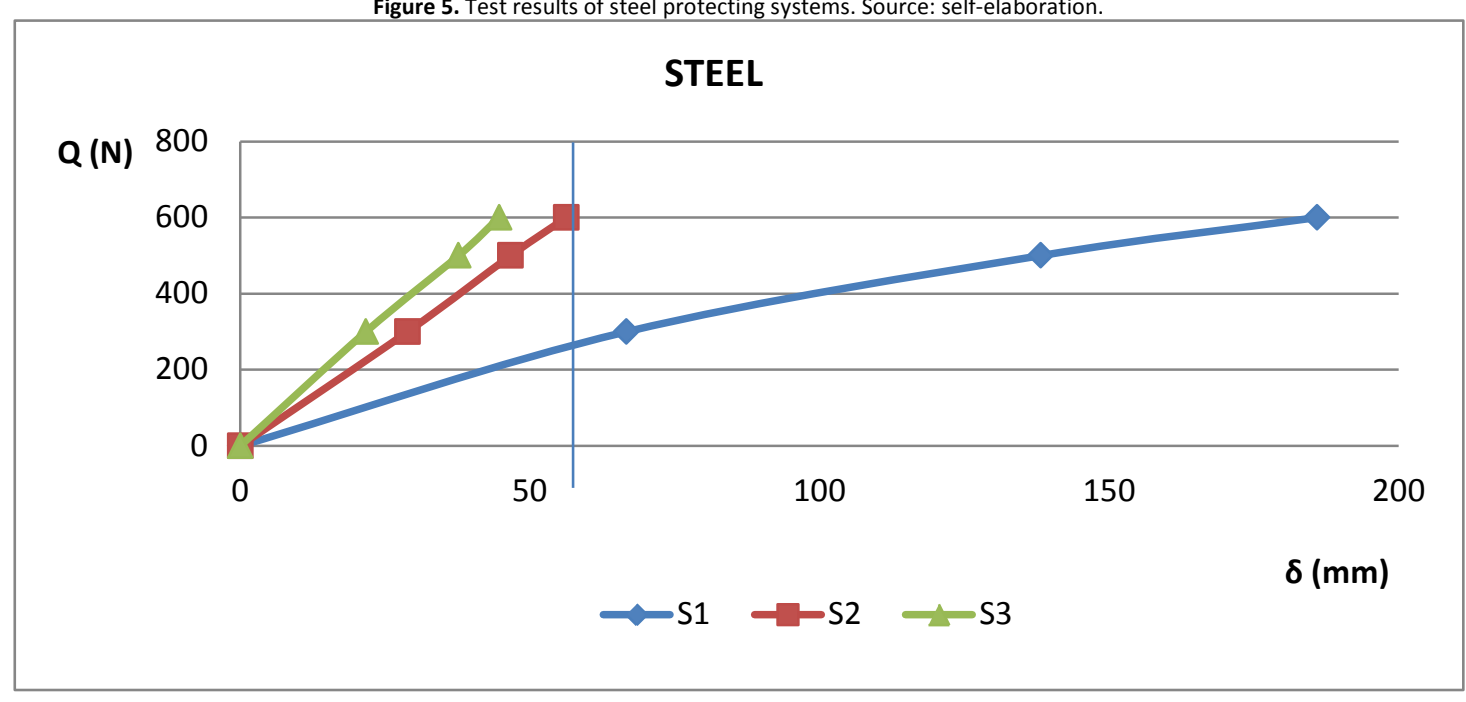

Figure 6. Test results of systems with wooden plank rails of thickness $22 \mathrm{~mm}$. Source: self-elaboration.

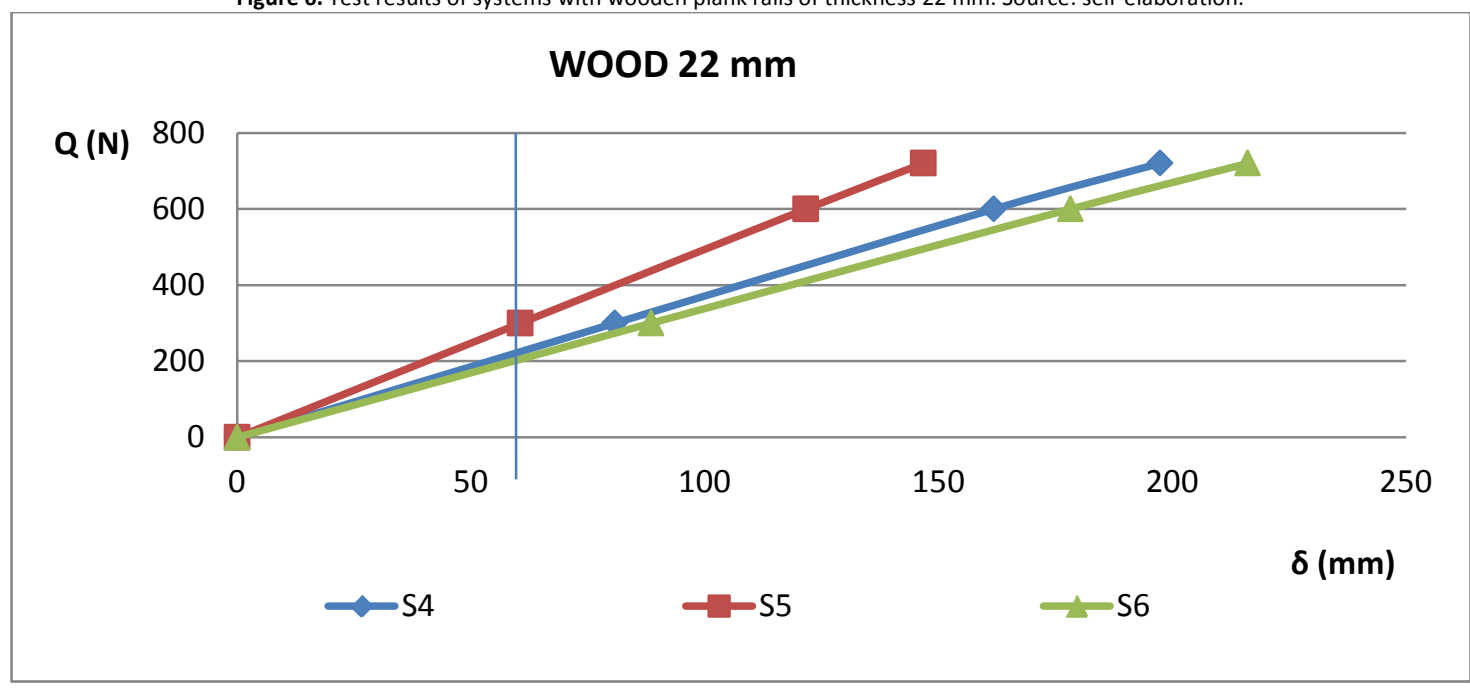


Figure 7. Test results of system with wooden plank rails of thickness $27 \mathrm{~mm}$. Source: self-elaboration.

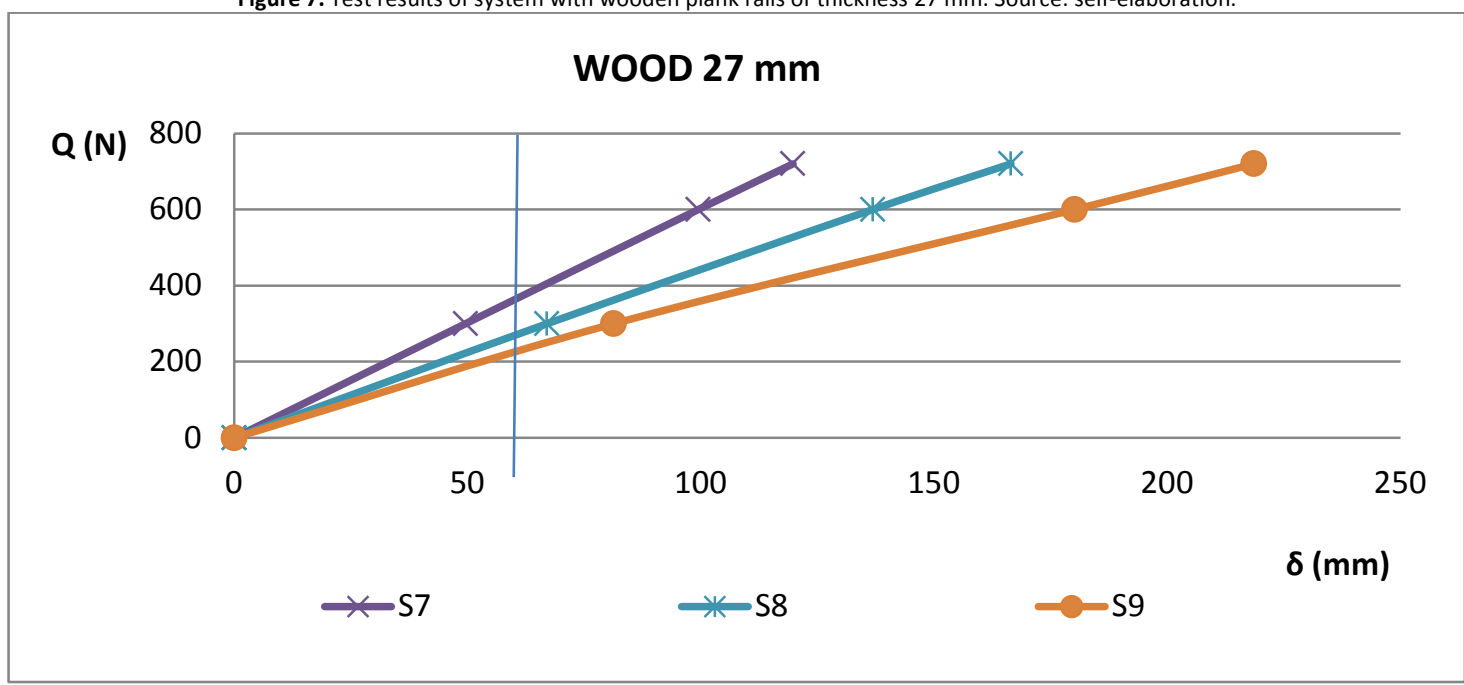

Figure 8. Test results of system with wooden plank rails of thickness $30 \mathrm{~mm}$. Source: self-elaboration.

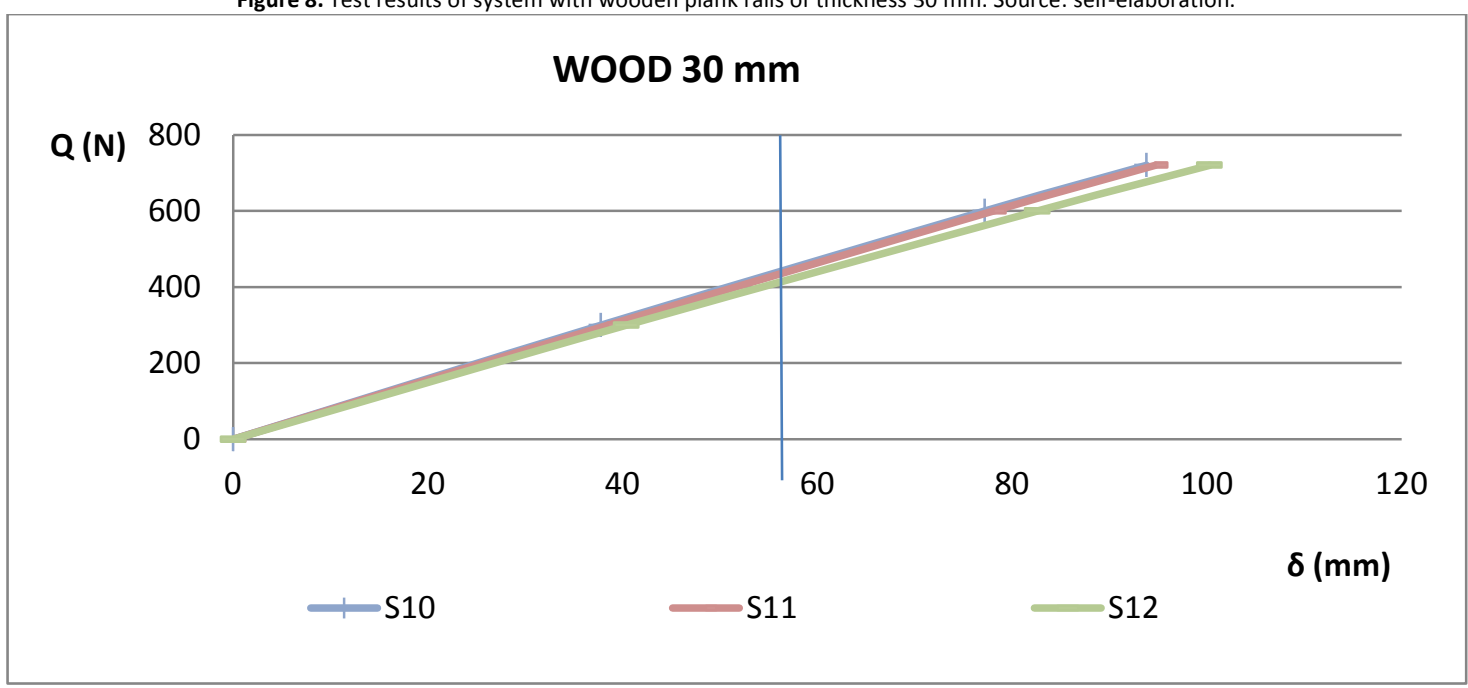

Figure 9. Strength test results of HDPE and HDPE+GF systems. Source: self-elaboration.

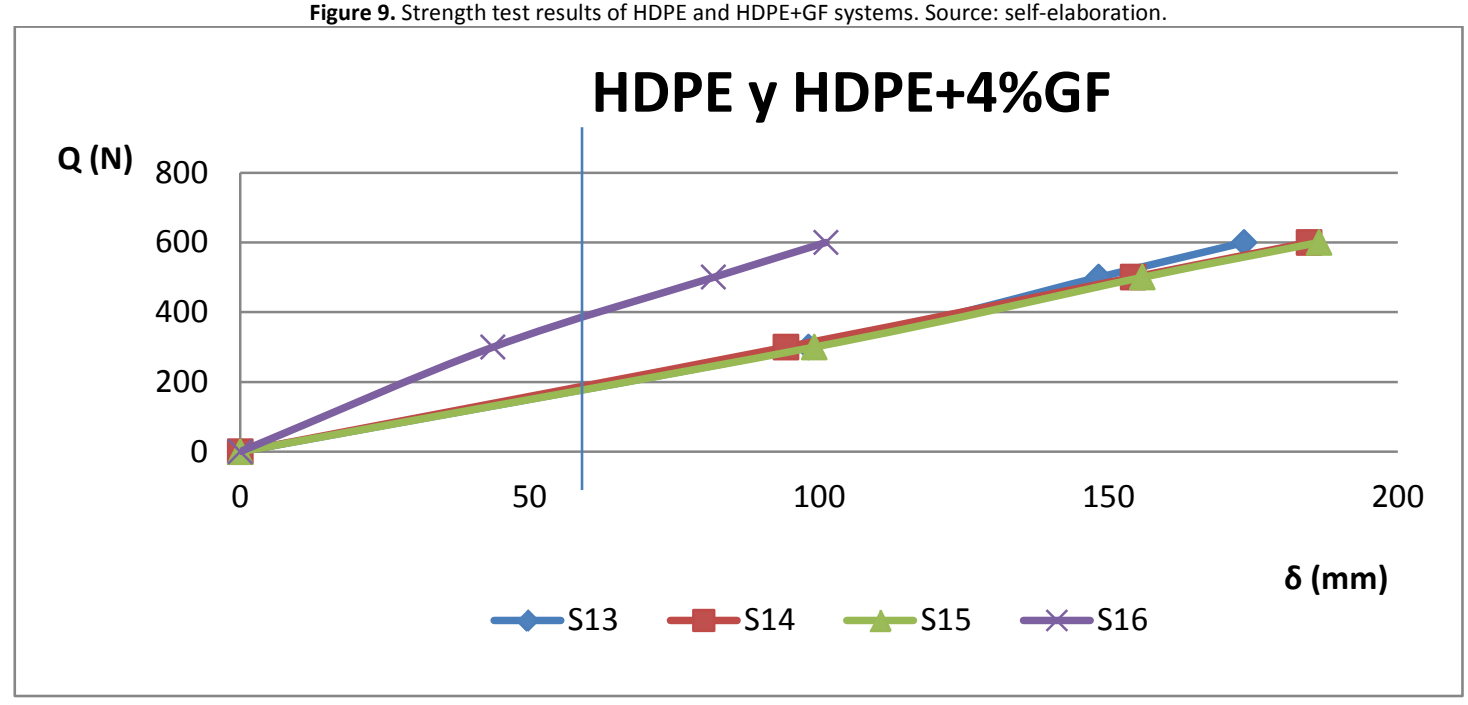




\section{Testing SLS}

In all systems studied, meeting the requirement of the service limit state has been the most demanding, and it was observed that the more flexible systems experienced greater displacements than those permitted by the standard.

In the steel systems, railings consisting of $25 \cdot 1.5$ tubes (the most commonly used solution) experienced a displacement of $66.7 \mathrm{~mm}$ during the displacement test. S2 and S3 systems were able to satisfactory overcome the assessment (table 3 and figure 5). Regarding wooden systems, the ones of $30 \mathrm{~mm}$ thickness are the only ones that exceed the standard requirements in any quality, and $27 \mathrm{~mm}$ thickness ones in ME1 quality (table 3 and figures 6,7 and 8). In relation to the plastic systems, fences built with HDPE experienced large displacements, well above the 55 $\mathrm{mm}$ permitted. Aging has not affected the behavior in any of the tested systems. The addition of $4 \%$ glass fiber conform a more rigid material (S16) which is able to pass the bending test (table 3 and figure 9).

\section{Testing ULS}

All systems were able to satisfactorily meet the ULS test requirements. However, the behavior of the systems has been very different. Within the steel systems, system S1 shows a linear behavior until a $400 \mathrm{~N}$ load is applied. From that specific load value, non-linear deformations occur with a gradual loss of rigidity. The other systems have a practically linear behavior until they reach the ultimate limit state. All wooden systems show a linear behavior until they reach the ultimate limit state, regardless of the quality of the wood used and the thickness.

The four systems manufactured in HDPE show a very linear behavior until a load of $300 \mathrm{~N}$ is applied. From that value onwards, systems with no addition of glass fiber show a slight stiffening when subjected to load increases. Conversely, systems with glass fiber addition lose rigidity as the load increases. This highlights the great difference in stiffness of HDPE+GF TEPS when compared to the HDPE as can be seen in the descending curve of the graph (Figure 9). All the four tested systems are able to reach the established test load.

\section{Energy absorbed during the test}

For each test, the energy absorbed by the system has been suggested, measured as the area enclosed by the loaddisplacement curve. The last column states the percentage value of the energy absorbed in the ultimate strength test regarding $180 \mathrm{~J}$ value. It can be observed that in all cases the absorbed energy in every test performed remains well below $180 \mathrm{~J}$, which suggests that the tests specified in the EN 13374 standard do not necessarily mean that systems which meet the standard are capable of retaining the impact of a worker. By applying the maximum load corresponding to the ultimate strength, the absorbed energy does not reach $50 \%$ of the energy corresponding to the worker impact, in none of the systems studied. In addition, systems that are not able to meet the standard due to their lower rigidity have led to displacements greater than $55 \mathrm{~mm}$ in the displacement test, are they the ones which have resulted in higher energy absorbed values. This suggests the need to perform further additional checks in the testing protocol of the EN 13374 standard when assessing the strength of systems. To this end, we propose that in the strength test, the load should be increasingly applied until an absorbed energy of at least $180 \mathrm{~J}$ is reached in the test.

Class A TEPS are tested with static loads, however, it is intended to meet requirements of dynamic type ones. The testing requirements established by the EN 13374 standard for SLS is more demanding than the ULS one. All systems have met the ULS testing, however 9 systems have not passed the test standard for SLS. The 16 tested TEPS have been able to achieve the maximum load specified by the EN 13374 standard in the strength test for the class A TEPS evaluation performed. None of the 16 tested TEPS have absorbed an energy of $180 \mathrm{~J}$ during the tests. Systems that do not meet the SLS test standard give rise to higher absorbed energies in static tests, due to the greater displacements they experienced. It is necessary to incorporate additional checks in the strength test in order to ensure that the systems are capable of absorbing an energy of $180 \mathrm{~J}$. 
AENOR (2013). UNE-EN 13374. Sistemas provisionales de protección de borde. Especificaciones del producto, métodos de ensayo. Asociación Española de Normalización, Madrid.

AENOR (2011). UNE 56544. Clasificación visual de la madera aserrada para uso estructural. Madera de coníferas. Asociación Española de Normalización, Madrid.

AENOR (2010). UNE 338. Madera estructural. Clases resistentes. Asociación Española de Normalización, Madrid.

AFNOR (2010). NF P 93-355. Équipements de chantier. Protection périphérique temporaire pour travaux d’étanchéité en toiture. Spécification du produit, méthode d'essai. Protection temporaire. 22 octobre 2010. Normalisation. Paris.

Australian Standard (1992). Fixed platforms, walkways, stairways and ladders-Design, construction and installation. Standards Association of Australia.

ASTM E 985-87 (1987). Standard Specification for Permanent Metal Railing Systems and Rail for Buildings. American Society for Testing and Materials, Philadelphia, PA.

BLS (2010). Bureau of labor Statistics. Fatal occupational injuries by event or exposure, 2007-2008.

eLCOSH (2008). Guiones orientadores para la protección anticaída de alturas. Biblioteca Electrónica de Salud y Seguridad Ocupacional en la Construcción. $\quad$ Retrieved from: http://www.elcosh.org/document/2264/d000052/Guiones\%2Borientadore s\%2Bpara\%2Bla\%2Bprotecci\%25C3\%25B3n\%2Bantica\%25C3\%25ADda\%2Bde\%2Balturas.html

González, M.N. (2010). Consideraciones respecto a los sistemas provisionales de protección de borde. Phd Thesis. Universidad Politécnica de Madrid, Madrid.

González, M.N., Cobo, A., Castaño, Á. \& Prieto, M.I. (2015). A comparison of the resistance of Temporary Edge Protection Systems to static and dynamic loads. Informes de la Construcción, 67(538). doi:10.3989/ic.13.161

González, M.N., Cobo, A., Fuente, J.V., Bresó, S. \& Lozano, C. (2010). Behavior under static loads of temporary edge protection systems built with Steel elements. Informes de la Construcción, 63(521), 57-67. doi:10.3989/ic.09.070

González, M.N., Cobo, A., Lozano, C. \& Bresó, S. (2013). Behaviour of Temporary Edge Protection Systems of high density polyethylene tested to static and impact load. Materiales de Construcción, 63(310), 283-296. doi:10.3989/mc.2012.07111

INRS. (2007). Institut National de Recherche et de Sécurité. Fiche pratique de sécurité ED 130. La prévention des chutes de hauteur. 1er édition, novembre.

Jacmin, M. \& Mayer, A. (1984). Écran garde-corps-protection contre les chutes de grande hauteur pour les travaux d'étanchéité en toiture. Édition INRS ED 1180. Paris.

Lan, A. \& Daigle, R. (2009). Development and validation of a method for evaluating temporary wooden guardrails built and installed on construction sites. Safety Science, 47(2), 215-226. doi:10.1016/j.ssci.2008.03.001

Lopez-Arquillos, A. \& Rubio-Romero, J. (2015). Proposed indicators of prevention through design in construction projects. Revista de la Construcción, 14(2), 58-64. http://dx.doi.org/10.4067/S0718-915X2015000200008.

Ministerio de Trabajo y Asuntos Sociales (2008). Instituto Nacional de Seguridad e Higiene en el Trabajo. VI Encuesta Nacional de condiciones de trabajo. NIPO: 211-07-057-0. from: http://oe.uvigo.es/asignaturas/gestioncalidad/VI\%20Encuesta\%20Nacional\%20de\%20Condiciones\%20de\%20Trabajo.pdf

National Safety Council (2002). Report on injuries in America, 2002. Itasca, IL.

OSHA (1998). Part 1926 Subpart M CFR 1926.500 - Fall Protection for the Construction Industry. Occupational Safety \& Health Administration. US Department of Labor, Washington, DC.

OSHA (1990). Analysis of Construction Fatalities. The OSHA Data Base 1985-1989. U.S. Department of labor, Washington, DC.

SESS (1999). Service d'expertise et soutien statistique, IRSST-Sources: Base de données de l'INFOCENTRE de la CSST, mise à jour au 1 mai 1999. 